\title{
Mechanisms of diversity maintenance in dung beetle assemblages in a heterogeneous tropical landscape
}

\author{
Jose D. Rivera ${ }^{\text {Corresp., } 1,2}{ }^{\text {, Benigo Gómez }}{ }^{1}$, Darío A. Navarrete-Gutiérrez ${ }^{3}$, Lorena Ruíz-Montoya ${ }^{1}$, Leonardo Delgado ${ }^{4}$, \\ Mario E. Favila ${ }^{2}$ \\ 1 Departamento Conservación de la Biodiversidad, El Colegio de la Frontera Sur, San Cristóbal de las Casas, Chiapas, Mexico \\ 2 Red de Ecoetología, Instituto de Ecología, A.C., Xalapa-Enriquez, Veracruz, Mexico \\ 3 Laboratorio de Análisis de Información Geográfica y Estadística, El Colegio de la Frontera Sur, San Cristóbal de las Casas, Chiapas, Mexico \\ 4 Red de Biodiversidad y Sistemática, Instituto de Ecología, A.C., Xalapa-Enriquez, Veracruz, Mexico \\ Corresponding Author: Jose D. Rivera \\ Email address: jdr495@hotmail.com
}

Background. Anthropized landscapes play a crucial role in biodiversity conservation, as they encompass about $90 \%$ of the remaining tropical forest. Effective conservation strategies require a deep understanding of how anthropic disturbances determine diversity patterns across these landscapes. Here, we evaluated how attributes and assembly mechanisms of dung beetle communities vary across the Selva El Ocote Biosphere Reserve (REBISO) landscape.

Methods. Community attributes (species diversity, abundance, and biomass) were assessed at the landscape scale, using spatial windows and vegetation classes. Windows were categorized as intact, variegated, or fragmented based on their percent cover of tropical forest. The vegetation classes analyzed were tropical forest, second-growth forest, and pastures.

Results. We collected 15,457 individuals and 55 species. Variegated windows, tropical forests, and second-growth forests showed the highest diversity values, while the lowest values were found in intact windows and pastures. Landscape fragmentation was positively and strongly related to dung beetle diversity and negatively related to their abundance; biomass was positively associated with forest cover. Beta diversity was the primary driver of the high dung beetle diversity in the landscape analyzed.

Discussion. The landscape heterogeneity and its biodiversity-friendly matrix facilitate the complementarity of dung beetle assemblages in the Selva El Ocote Biosphere Reserve. Random processes govern beta diversity patterns in intact and variegated windows. Therefore, vegetation cover in the region is sufficient to maintain a continuous flow of dung beetles between forested landscape segments. However, intense anthropic disturbances acted as deterministic environmental filters in fragmented windows and pastures sites, leading to biotic homogenization processes. Our results suggest that increasing habitat variegation in highly fragmented sites is an effective strategy to prevent or buffer homogenization processes in the REBISO landscape. 
1 Mechanisms of Diversity Maintenance in Dung Beetle Assemblages in a

2 Heterogeneous Tropical Landscape

3

4 Jose D. Rivera ${ }^{1,2}$, Benigno Gomez ${ }^{1}$, Dario A. Navarrete-Gutiérrez ${ }^{3}$, Lorena Ruiz-Montoya ${ }^{1}$,

5 Leonardo Delgado ${ }^{4}$, Mario E. Favila ${ }^{2}$

6

$7 \quad{ }^{1}$ Departamento Conservación de la Biodiversidad, El Colegio de la Frontera Sur, San Cristóbal

8 de las Casas, Chiapas, Mexico

$9 \quad 2$ Red de Ecoetología, Instituto de Ecología A.C., Xalapa-Enríquez, Veracruz, Mexico

$10{ }^{3}$ Laboratorio de Análisis de Información Geográfica y Estadística, El Colegio de la Frontera Sur,

11 San Cristóbal de las Casas, Chiapas, Mexico

$12{ }^{4}$ Red de Biodiversidad y Sistemática, Instituto de Ecología A. C., Xalapa-Enríquez, Veracruz,

13 Mexico

14

15 Corresponding author:

16 Jose D. Rivera ${ }^{1}$

17 Carretera antigua a Coatepec No. 351, El Haya, Xalapa-Enríquez, Veracruz, 91073, Mexico

18 Email address: jdr495@hotmail.com 


\section{Abstract}

22

Background. Anthropized landscapes play a crucial role in biodiversity conservation, as they encompass about $90 \%$ of the remaining tropical forest. Effective conservation strategies require a deep understanding of how anthropic disturbances determine diversity patterns across these landscapes. Here, we evaluated how attributes and assembly mechanisms of dung beetle communities vary across the Selva El Ocote Biosphere Reserve (REBISO) landscape. Methods. Community attributes (species diversity, abundance, and biomass) were assessed at the landscape scale, using spatial windows and vegetation classes. Windows were categorized as intact, variegated, or fragmented based on their percent cover of tropical forest. The vegetation classes analyzed were tropical forest, second-growth forest, and pastures.

Results. We collected 15,457 individuals and 55 species. Variegated windows, tropical forests, and second-growth forests showed the highest diversity values, while the lowest values were found in intact windows and pastures. Landscape fragmentation was positively and strongly related to dung beetle diversity and negatively related to their abundance; biomass was positively associated with forest cover. Beta diversity was the primary driver of the high dung beetle diversity in the landscape analyzed.

Discussion. The landscape heterogeneity and its biodiversity-friendly matrix facilitate the complementarity of dung beetle assemblages in the Selva El Ocote Biosphere Reserve. Random processes govern beta diversity patterns in intact and variegated windows. Therefore, vegetation cover in the region is sufficient to maintain a continuous flow of dung beetles between forested landscape segments. However, intense anthropic disturbances acted as deterministic environmental filters in fragmented windows and pastures sites, leading to biotic homogenization processes. Our results suggest that increasing habitat variegation in highly fragmented sites is an effective strategy to prevent or buffer homogenization processes in the REBISO landscape.

\section{Introduction}

Anthropized neotropical landscapes encompass a complex combination of natural and seminatural habitats, where some species can thrive while others may go locally extinct (de Castro Solar et al., 2015). Today, almost $90 \%$ of remaining tropical forests are located within anthropized landscapes (Chazdon et al., 2009). These landscapes now play a crucial role in biodiversity conservation agendas (DeClerck et al., 2010). Therefore, it is imperative to understand how species diversity responds to anthropized landscapes in order to implement suitable management actions (Gardner et al., 2009; Socolar et al., 2016), especially given the multiple successional pathways and disturbance states that these modified landscapes can follow (Fischer \& Lindenmayer, 2007; Arroyo-Rodríguez et al., 2017).

Traditionally, researchers have assessed the effect of anthropic disturbance on biotic communities by comparing one or more community attributes (e.g., species diversity, abundance, biomass) across different sampling units at a local level (i.e., vegetation cover types or land-use 
61 types). However, the composition and configuration of the habitats that surround the sampling 62 units are also important drivers of ecological processes in biotic communities (Franklin \& 63 Lindenmayer, 2009). A landscape-level approach provides the necessary context to understand better how communities respond to anthropic disturbances by incorporating the effects of the multiple landscape components (Gardner et al., 2009; Hodder et al., 2014). Besides, landscape studies provide useful information for effective natural resource management since many anthropogenic drivers of biodiversity loss, e.g., land-use change or habitat destruction, operate at the landscape level (Hodder et al., 2014).

McIntyre and Barret (1992) coined the variegation concept for anthropized landscapes exhibiting disturbance and vegetation cover gradients. McIntyre and Hobbs (1999) then added the fragmentation concept to the variegation model. These authors classified the landscape into four categories based on the percentage of remaining original vegetation (OV) and the intensity of habitat transformation: a) intact landscapes $(>90 \% \mathrm{OV})$ : sites with little or no modification; b) variegated landscapes (60-90\% OV), showing either gradual or abrupt limits between their component units; c) fragmented landscapes $(10-60 \%$ OV), characterized by a high degree of modification; and d) relict landscapes $(<10 \% \mathrm{OV})$, showing severe modification and almost no forest cover remnants. Halffter and Rös (2013) proposed studying landscape diversity through sampling windows in the geographical space analyzed. These windows are based on the landscape model proposed by McIntyre and Hobbs (1992) and consist of equally-sized sampling spaces that are semi-randomly located to maximize the representation of the vegetation heterogeneity and land-use types in the landscape.

The Selva El Ocote Biosphere Reserve (REBISO, hereafter) harbors some of the most heterogeneous, although highly disturbed, remnants of tropical forest in Mexico (FlamencoSandoval, Martínez Ramos \& Masera, 2007). Frequent forest fires, in addition to the complex geological nature, climate features, and socio-economic dynamics (livestock and agricultural activities) in the REBISO have led to a complex landscape comprising a mosaic of tropical forests, second-growth forests, pastures, and croplands (Ochoa, 1996; SEMARNAT/CONANP, 2001; Flamenco-Sandoval, Martínez Ramos \& Masera, 2007; Ramírez-Marcial et al., 2017). Thus, a landscape-level approach seems most appropriate for examining how species respond to anthropogenic disturbance in the REBISO, given its complex and heterogeneous landscape.

Dung beetles (Scarabaeidae: Scarabaeinae) are globally distributed insects that feed on decomposing organic matter such as mammal feces, carrion, rotting fruit, or fungi (Halffter \& Matthews, 1966). Due to their sensitivity to environmental disturbances, dung beetles are ideal bioindicators to assess the effects of landscape changes on diversity (Favila \& Halffter, 1997; Nichols et al., 2007). Previous studies have shown how habitat loss leads to abrupt changes in the composition and structure of dung beetle communities (Klein, 1989; Quintero \& Roslin, 2005; Nichols et al., 2007; Navarrete \& Halffter, 2008; Díaz, Galante \& Favila, 2010; Cajaiba et al., 2017). However, few studies have evaluated the response of dung beetle communities to disturbances at the landscape level (Numa et al., 2009; Rös, Escobar \& Halffter, 2012; Sánchezde-Jesús et al., 2016; Alvarado et al., 2018, 2020), or whether the observed diversity patterns are

Peer) reviewing PDF | (2020:03:46967:2:0:NEW 5 Aug 2020) 
101 stochastic or determined by environmental filters or competitive exclusion between species

102 (Ortega-Martínez et al., 2020). Assessing dung beetle diversity at the landscape level, using

103 multiple but complementary metrics, can provide a more comprehensive view of how diversity is

104 maintained and what community assembly mechanisms operate in anthropized landscapes.

105 In this study, we evaluate the assemblage structure and diversity patterns of dung beetle

106 communities in the heterogeneous tropical landscape of the Selva El Ocote Biosphere Reserve.

107 We address the following questions: (1) How do the diversity and structure of dung beetle

108 assemblages vary across the REBISO landscape and its vegetation classes? (2) How do the

109 composition and configuration of the REBISO landscape influence the diversity and structure of

110 dung beetle assemblages? (3) How does beta diversity change and is maintained across the

111 landscape and between different vegetation classes? The information obtained in this study will

112 be useful for designing conservation strategies in complex tropical landscapes with different

113 heterogeneity levels.

114

115

Materials \& Methods

116

117

Study Area

118

119

The study was carried out at the REBISO, located in the municipalities of Ocozocoautla de

120

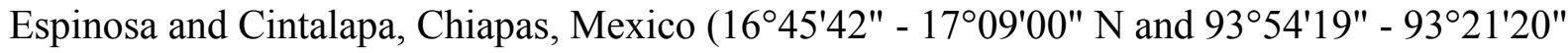

121 W, Fig. 1). The area is mostly underlain by dolomite rocks and limestone, with a dominance of

122 water-soluble sedimentary rocks (Domenici, 2016). The predominant climate types are warm, humid (climate type Am) and warm, subhumid (climate type Am(f)), with a mean annual temperature of $22^{\circ} \mathrm{C}$ and heavy rainfall throughout the year (SEMARNAT/CONANP, 2001).

We produced a vegetation map of REBISO from a multispectral SPOT6 image acquired in 2014, using a supervised classification method in QGIS v2.12.3 (QGIS Development Team, 2016). The vegetation classes considered were tropical forest, second-growth forest, and pastures

128 (Fig. 1, Table 1).

129

130

131

132

133

\section{Sampling Design}

We established eight $1-\mathrm{km}^{2}(100 \mathrm{ha})$ sampling windows to capture the landscape heterogeneity

134 in the REBISO (Sánchez-de-Jesús et al., 2016). Each window was separated from each other by at least $2 \mathrm{~km}$ to ensure spatial independence between them (Sánchez-de-Jesús et al., 2016). The landscape composition in each window was described by estimating the percent coverage of each vegetation class and evaluating the evenness of their distribution (landscape compositional diversity - Shannon diversity). The spatial configuration of the vegetation classes in each window was assessed with the splitting index and edge density metric (McGarigal, Cushman \& Ene, 2012). Edge density is computed as the length (m) of the edges of each vegetation class divided by the window area (ha). The splitting index describes the degree of fragmentation of a landscape and is equivalent to the effective number of patches. Thus, as a landscape becomes 
142 increasingly sub-divided, the splitting index increases (Jaeger, 2000; Fahrig, 2017). The

143 landscape composition, edge density, and splitting index metrics (Table S1) were obtained with

144 FRAGSTAT v4.2.1 (McGarigal et al., 2012). Based on the percent cover of tropical forest (F),

145 windows were classified as intact (W1, W2; F $>90 \%$ ), variegated (W3, W4, and W5; 60\% $<$ F < $14690 \%$ ), or fragmented (W6, W7, and W8; 10\% $<\mathrm{F}<60 \%$ ).

147 We sampled dung beetles (Scarabaeidae: Scarabaeinae) during the dry (March to May)

148 and the rainy (July-August) seasons of 2016 using pitfall traps. This sampling scheme allowed us

149 to integrate the seasonal activities of dung beetles (Cajaiba et al., 2017). Each trap consisted of a

$1501 \mathrm{~L}$ cylindrical plastic container with $300 \mathrm{~mL}$ of ethylene glycol as preservative, buried at ground

151 level, and covered with a plastic lid to protect the bait from rain and sun radiation. Pitfall traps

152 were baited with $70 \mathrm{~g}$ of either an 80:20 mixture of pig and human feces (copro-traps) or squid

153 flesh (necro-traps) in order to obtain a representative sample of the dung beetle assemblages in

154 the area.

155 Seven sampling sites were established in each window, separated 250-360 meters from

156 each other, to proportionally adjust the number of pitfall traps per vegetation class according to

157 the vegetation class composition of each window (Table S2). Proportional sampling is a suitable

158 method for detecting changes in beta diversity in heterogeneous landscapes (Schoereder et al.,

159 2004). In each sampling site, three copro-traps and three necro-traps (42 traps/window), were

160 placed in a rectangular area separated $50 \mathrm{~m}$ from each other to minimize interference between

161 them (Larsen \& Forsyth, 2005). The rectangular layout of some trap sets was modified in some

162 cases due to the topographic characteristics of the sites. The pitfall traps were left active for 48

163 hours.

164 The specimens collected were counted and identified to species. To estimate the dung beetle biomass, we randomly selected ten specimens of each species and dried them at $70{ }^{\circ} \mathrm{C}$ for 72 hours. We weighed each specimen to the nearest $0.1 \mathrm{mg}$ with an analytical balance (Explorer Pro) and calculated the average biomass for each species. Finally, we multiplied the mean biomass of each species by its abundance in each window and vegetation class. The dung beetle specimens were deposited in the entomological collection of El Colegio de la Frontera Sur, San Cristóbal de Las Casas. Field sampling in the REBISO was carried out under permit SGPA/DGS/14214/15 issued by the Secretaria de Medio Ambiente y Recursos Naturales, Mexico.

\section{Data Analysis}

We followed a spatial and structural approach (sensu Rös, Escobar \& Halffter, 2012) to analyze

177 the data. Windows were the sampling units for the spatial approach $(n=8)$, while vegetation

178 classes within windows were the sampling units for the structural approach $(n=21)$. The

179 sampling completeness of each window and vegetation class was determined using the coverage 180 estimator of Chao and Jost (2012), which allows comparing species diversity across multiple 181 sites. 
$182 \quad$ Alpha diversity in each sampling unit (window or vegetation class) was evaluated using 183 the ${ }^{0} D$ and ${ }^{1} D$ diversity numbers. ${ }^{0} D$ is equivalent to species richness and is insensitive to the 184 species abundance (Jost, 2006); ${ }^{1} D$ is equivalent to the exponential of Shannon diversity index 185 and accounts for the most abundant species in a community (Jost, 2006).

186 We examined differences in species richness between windows by constructing and 187 comparing their $95 \%$ bootstrap confidence intervals. Non-overlapping confidence intervals 188 denote significantly different species richness (Gotelli \& Colwell, 2011; Chao et al., 2014).

189 Differences in species richness between vegetation classes were determined using interpolation190 extrapolation curves (Chao et al., 2014). The sampling coverage, ${ }^{0} D$ and ${ }^{1} D$ diversity numbers,

191 confidence intervals, and the interpolation-extrapolation curves were obtained with the software 192 iNEXT v2.0.11 (Hsieh, Ma \& Chao, 2016).

193 Generalized linear models (GLM) were used to assess differences in abundance and

194 biomass between windows and vegetation classes. The abundance and biomass data approached

195 a normal distribution after logarithmic transformation and were analyzed assuming a Gaussian

196 error distribution (Crawley, 2013). Pairwise comparisons using Tukey's test were carried out,

197 with the multcomp package (Hothorn et al., 2016) whenever significant differences were

198 detected.

GLMs were also used to assess the effect of the landscape composition and configuration on the species richness $\left({ }^{0} D\right)$, exponential of the Shannon diversity $\left({ }^{1} D\right)$, abundance, and biomass of the dung beetle assemblages. These data were first tested for normality and were then analyzed assuming a Gaussian error distribution. Since only eight observations were available to fit these models, separate models containing only one predictor variable were constructed to avoid overfitting (Kelley \& Maxwell, 2003). The best-fit models were selected based on the Akaike's information criterion corrected for small samples (AICc) and the deviance explained $\left(\mathrm{D}^{2}\right)$. The model with the smallest AICc $(\triangle \mathrm{AICc}>2)$ and the largest $\mathrm{D}^{2}$ values was selected as the best-fit model (Burnham \& Anderson, 2002). Based on the results from the Moran I test (as implemented in the package LetsR), no significant spatial structure was detected in the response variables (Table S3) (Vilela \& Villalobos, 2015).

True beta diversity (i.e., the effective number of distinct communities) was estimated for species richness $\left({ }^{0} \beta\right)$ and Shannon diversity $\left({ }^{1} \beta\right)$ using the multiplicative partitioning method

212 (Jost, 2007). The multiple-site Sørensen dissimilarity was partitioned as $\beta_{\text {Sor }}=\beta_{\text {Sim }}+\beta_{\text {Sne }}$ using

213 the package Betapart v1.3 (Baselga \& Orme, 2012) to determine whether the ecological

214 differences between sampling units resulted from species turnover $\left(\beta_{\mathrm{Sim}}\right)$ or nestedness $\left(\beta_{\mathrm{Sne}}\right)$.

215 Turnover measures the replacement of species between sites caused by environmental

216 differences, disturbance, or competition. Nestedness is a loss of species between sites, usually

217 due to differences in local conditions or ecological niches, where the species-poorer site contains

218 a subset of the species present in the species-richer site (Legendre, 2014).

Null models were used to determine whether beta diversity patterns resulted from either

220 random changes in alpha and gamma diversity, or from underlying deterministic mechanisms in communities or the landscape (Chase et al., 2011). We constructed null models for the beta 
222 Raup-Crick index ( $\beta_{\mathrm{R}-\mathrm{C}}$ ) using the algorithm developed by Chase et al. (2011) with 9999

223

224

225

226

227

228

229

230

231

232

233

234

235

236

237

238

239

240

241

242

243

244

245

246

247

248

249

250

251

252

253

254

255

256

257

258

259

260

261

262

randomizations. $\beta_{\mathrm{R}-\mathrm{C}}$ compares the observed versus expected beta diversity under the null model, scaling the results to a range between -1 and 1 . This value indicates whether the beta diversity observed between windows, or vegetation classes, is more similar (values close to -1), equal (values close to 0 ), or less similar (values close to 1 ) than the one expected by chance ( $\beta_{\mathrm{R}-\mathrm{C}}$ null model). We built a dendrogram and a nonmetric multidimensional scaling (NMDS) plot based on $\beta_{\mathrm{R}-\mathrm{C}}$ values for windows and vegetation classes, respectively (Chase et al., 2011). The dendrogram was constructed using the complete linkage method, as it produces clusters with ecological discontinuities (Legendre \& Legendre, 2003). We compared the dendrogram and NMDS plot based on $\beta_{\mathrm{R}-\mathrm{C}}$ with homologous plots based on Sørensen dissimilarity to examine whether deterministic mechanisms are underlying the observed beta diversity across the landscape (Chase et al., 2011). All statistical analyses and models were carried out using R v.3.3.1 (R Development Core Team, 2015).

\section{Results}

We collected a total of 15,457 specimens belonging to 55 species in the eight windows at REBISO (Table S4a). The most abundant species was Deltochilum mexicanum (15\% of total abundance), followed by Onthophagus corrosus (13\%), Eurysternus maya (12\%), Canthon vazquezae (11\%), and Onthophagus batesi (8\%). Sampling coverage on each window was $99 \%$ (Table S4a). However, the sampling coverage of vegetation classes varied between windows: for forest vegetation it ranged from 91\% (W6) to 100\% (W8), it was over 98\% for second-growth forests, and between 95\% (W3) and 99\% (W6) for pastures (Table S4a).

\section{Diversity, Abundance, and Biomass Patterns in Windows}

Species richness $\left({ }^{\circ} D\right)$ in the windows sampled ranged from 22 (W1, intact window) to 37 (W4, variegated window), whereas the exponential Shannon diversity index $\left({ }^{1} D\right)$ ranged from 4.9 (W2, intact window) to 17.6 (W5, variegated window) species (Table 2). Species richness in W4 and W5 was significantly higher than in the other windows (Fig. 2a).

Deltochilum mexicanum, E. maya, and C. vazquezae were the most abundant species in intact windows W1 and W2 (Fig S1a); C. vazqueze, E. maya, and Eurysternus angustulus were the most abundant ones in variegated windows W3, W4, and W5; and O. batesi, O. corrosus, and Copris lugubris were the most abundant species in fragmented windows W6, W7, and W8 (Fig S1a). Biomass patterns in the dung beetle communities differed from those observed in their abundance values. Deltochilum mexicanum, E. maya, and Ontherus mexicanus were the dominant species, in terms of biomass, in intact windows W1 and W2 (Fig S1a); D. mexicanum, E. maya, and Dichotomius amplicollis were the dominant species in W3; D. mexicanum, D. amplicollis, and Dichotomius annae in W4; and Coprophanaeus corythus, Deltochilum sublaeve, and D. amplicollis in W5. Coprophanaeus corythus, C. lugubris, and D. amplicollis were the species with the highest biomass in fragmented windows W6, W7, and W8 (Fig S1a).

Peer) reviewing PDF | (2020:03:46967:2:0:NEW 5 Aug 2020) 
The highest abundance values (44-52 individuals per trap) were recorded in the intact

264

265

266

267

268

269

270

271

272

273

274

275

276

277

278

279

280

281

282

283

284

285

286

287

288

289

290

291

292

293

294

295

296

297

298

299

300

301

302

windows W1 and W2 (Table 3), followed by fragmented windows W6, W7, and W8 (30-36 individuals per trap), and variegated windows $\mathrm{W} 3, \mathrm{~W} 4$, and W5 (15-30 individuals per trap). However, these differences were not statistically significant $\left(\chi^{2}=8.923 ; \mathrm{df}=7 ; \mathrm{P}=0.26\right.$; Table $3)$. By contrast, there were significant differences in mean biomass between windows $\left(\chi^{2}=\right.$ $45.143 ; \mathrm{df}=7 ; \mathrm{P}=>0.001$; Table 3$)$. Mean biomass per trap was significantly higher in windows W1 and W2 (8.2-9.1 grams per trap, Table 3), but no significant differences were found between fragmented (2.2-3.7 grams per trap, Table 3) and variegated windows (2.4-3.9 grams per trap, Table 3).

All the landscape variables had a significant positive effect on the species richness $\left({ }^{0} D\right)$ in each window. However, the splitting index was the variable that best explained variations in species richness (Table 4). Although the exponential Shannon diversity $\left({ }^{1} D\right)$ values were positively related to the splitting index and edge density, the splitting index was the best predictor for variations in Shannon diversity between windows. Edge density and forest cover were the best predictor variables for dung beetle abundance and biomass, respectively; edge density was negatively correlated with abundance, and forest cover positively correlated with biomass (Table 4).

True beta diversity of orders 0 and 1 indicated two effective communities between windows, ${ }^{0} \beta$ being slightly smaller than ${ }^{1} \beta$ (Table 2 ). The multiple-site Sørensen value calculated for all windows was 0.65 (Fig. 3a "W Total"); $85 \%$ of this dissimilarity was due to species turnover $\left(\beta_{\text {Sim }}\right)$ and $15 \%$ to nestedness-resultant component $\left(\beta_{\text {Sne }}\right)$. Sørensen dissimilarity for intact windows W1 and W2 was lower than 0.4, mainly due to nestedness ( $\left.\beta_{\text {Sne }}\right)$ (Fig. 3a). Dissimilarity ranged from 0.3 to 0.45 in variegated windows (W3, W4, W5), and from 0.3 to 0.58 in fragmented windows (W6, W7, W8). In most cases (except for W8), the observed Sørensen dissimilarity values were primarily due to species turnover (Fig. 3a).

The dendrogram based on the Sørensen distance revealed two main groups (Fig. 3b). The first group includes the fragmented windows (W6, W7, W8), while the second group reveals a gradient of increasing similarity ranging from the intact (W1, W2) to the variegated (W3, W4, W5) windows. The null-model analysis showed that the difference between fragmented windows with respect to the variegated and intact windows was higher than expected by chance $\left(\beta_{\mathrm{RC}}\right.$ Value: 1.0, Fig. 3c). However, the dissimilarity between variegated and intact windows did not exceed the null expectation of beta diversity $\left(0<\beta_{\mathrm{RC}}<0.3\right.$, Fig. $\left.3 \mathrm{c}\right)$.

\section{Diversity, Abundance, and Biomass in Vegetation Classes}

The dung beetle species richness ( ${ }^{0} D=34$ species) in pastures was significantly lower than in the other vegetation classes, but there were no significant differences between second-growth and tropical forests (44 and 45 species, respectively) (Fig. 2b). We recorded the lowest exponential Shannon diversity values $\left({ }^{1} D\right)$ in the tropical forests $(7.75)$ and the highest in second-growth forests (15.54) (Table 2).

Peer) reviewing PDF | (2020:03:46967:2:0:NEW 5 Aug 2020) 
303

304

305

306

307

308

309

310

311

312

313

314

315

316

317

318

319

320

321

322

323

324

325

326

327

328

329

330

331

332

333

334

335

336

337

338

339

340

341

342

343

Deltochilum mexicanum, C. vazquezae, and E. maya were the most abundant species in tropical forest sites (Fig S1b); O. corrosus, D. mexicanum, and E. maya in the second-growth forest; and O. batesi, O. corrosus, and C. lugubris in pasture sites (Fig S1b). Deltochilum mexicanum, E. maya, and O. mexicanus contributed with the highest biomass in tropical forests; D. mexicanum, C. corythus, and E. maya in the second-growth forests (Fig S1b); and $C$. corythus, C. lugubris, and D. amplicollis in pasture sites (Fig S1b).

No significant differences in abundance were observed between vegetation classes $\left(\chi^{2}=\right.$ $3.701 ; \mathrm{df}=2 ; \mathrm{P}=0.16$, Table 3 ). The average number of individuals per trap was 37.8 in secondgrowth forests, followed by tropical forests (30.2) and pasture sites (17.7) (Table 3). By contrast, there were significant differences in mean biomass between vegetation classes $\left(\chi^{2}=10.829 ; \mathrm{df}=\right.$ $2 ; \mathrm{P}=0.004)$. Pasture sites had a significantly lower mean biomass per trap $(2.09 \mathrm{~g})$ than tropical forest $(5.05 \mathrm{~g})$ and second-growth forest (4.53) sites, which showed no significant differences between them (Table. 3).

According to the multiplicative partition of diversity, there were 2.9 effective communities for ${ }^{0} \beta$ and 2.5 communities for ${ }^{1} \beta$ in the three vegetation classes combined. Two effective communities were estimated for both the tropical forest and second-growth forest classes, with ${ }^{1} \beta$ higher than ${ }^{0} \beta$ in both cases. Only one effective community was estimated for the pasture class, with ${ }^{0} \beta$ higher than ${ }^{1} \beta$ (Table 2 ). The Sørensen dissimilarity between vegetation classes was 0.85 , with $88 \%$ of this value accounted for by species turnover $\left(\beta_{\operatorname{Sim}}\right)$ and $12 \%$ by nestedness processes $\left(\beta_{\text {Sne }}\right)$ (Fig. 4b).

Tropical forests and second-growth forests showed higher Sørensen values $(0.71$ and 0.70 , respectively) than pastures (0.54) (Fig. 4a). The NMDS plot based on the Sørensen distance formed a compact cluster of pasture sites, whereas most of the tropical forest and second-growth forest sites overlapped between themselves and with the pasture sites. (Fig. 4b). The NMDS plot based on the beta Raup-Crick null model index $\left(\beta_{\mathrm{R}-\mathrm{C}}\right)$ separated the tropical forest sites from pastures, whereas second-growth forest sites overlapped with tropical forest and pasture classes (Fig. 4c).

\section{Discussion}

Our results identify the REBISO as one of the regions with highest diversity of Scarabaeinae in Mexican tropical forests, with 55 species, along with the Chimalapas, Oaxaca, with 74 species (Peralta Moctezuma, 2019); the Lacandon forest, Chiapas, with 49 species (Navarrete \& Halffter, 2008); and the Tuxtlas forest, Veracruz, with 44 species (Favila, 2005).

\section{Local Patterns of Species Richness and Assemblage Structure}

Dung beetle communities in variegated windows showed the highest richness values in the REBISO. Rös, Escobar \& Halffter (2012) and Costa et al. (2017) also found a higher richness of dung beetle species in variegated landscapes. Landscape variegation can be a significant environmental driver of local diversity as it increases the range of habitats available for species 
344 by creating a complex composition and configuration (Tscharntke et al., 2012; Ramírez-Ponce et 345 al., 2019). The high species richness and diversity found in variegated windows in the REBISO

346

347

348

349

350

351

352

353

354

355

356

357

358

359

360

361

362

363

364

365

366

367

368

369

370

371

372

373

374

375

376

377

378

379

380

381

382

383

384 can be attributed to the convergence of multiple dung beetle assemblages including forest specialists (e.g., Eurysternus caribaeus, Sulcophanaeus chryseicollis, and Uroxys boneti), forestpasture edge specialists (O. landolti, Canthon cyanellus), open habitat specialists (D. annae, $C$. lugubris, O. corrosus), and generalist beetles (O. batesi) (Favila, 2005; Navarrete \& Halffter, 2008).

Intact and fragmented windows showed lower diversity values than variegated windows. This diversity pattern is consistent with the intermediate disturbance theory (Grime, 1973). Sites with little or no disturbance favor the predominance of highly competitive forest specialists such as D. mexicanum, C. vazquezae, and E. maya, which accounted for $85 \%$ of the total abundance and $90 \%$ of the total biomass in intact windows, thus preventing a higher local diversity. On the other hand, the intense landscape changes caused by livestock production in fragmented windows reduce the local species richness of dung beetles since many native-forest species are unable to adapt to the new open habitat conditions (Halffter, Favila \& Halffter, 1992; Silva, Storck-Tonon \& Vaz-de-Mello, 2016; Alvarado et al., 2018).

The presence of the exotic African species Digitonthophagus gazella (Montes de Oca \& Halffter, 1998) in the REBISO is worth mentioning. Although D. gazella was only recorded in pastures of fragmented windows (W6, W7), and contributed with only a small fraction of the community abundance and biomass (six and four percent, respectively), they may pose competitive pressure on native species inhabiting open areas (Lobo \& Montes de Oca, 1994). Further studies are needed to assess how this invasive beetle might affect native species in the REBISO.

Dung beetles are involved, among other ecological processes, in the recycling of organic matter, soil bioturbation, and secondary seed dispersal (Nichols et al., 2008). The amounts of soil removed, dung buried, and seed dispersed are significantly and positively influenced by the species richness and biomass of dung beetle assemblages (Nunes et al., 2018; Alvarado, Dáttilo $\&$ Escobar, 2019). The tropical forest sites showed the highest dung beetle species richness and biomass values. Besides, forest coverage was positively related to dung beetle biomass in the REBISO. Both results indicate that the tropical forest sites likely contain the most functionally efficient dung beetle assemblages, thus emphasizing the importance of forest conservation in the REBISO.

\section{Effects of Landscape Composition and Configuration on Dung Beetle Assemblages}

Previous studies conducted in tropical ecosystems have identified landscape composition as the main predictor of the diversity of dung beetle assemblages (Sánchez-de-Jesús et al., 2016; Alvarado et al., 2018). However, in our study, landscape fragmentation was the primary explanatory variable of variations in species richness and diversity. These findings are likely due to the variegated structure of the REBISO landscape and its "biodiversity-friendly" matrix of second-growth forest (see Perfecto \& Vandermeer, 2008; Melo et al., 2013). First, second- 
385

386

387

388

389

390

391

392

393

394

395

396

397

398

399

400

401

402

403

404

405

406

407

408

409

410

411

412

413

414

415

416

417

418

419

420

421

422

423

424

425

growth forests in the REBISO are structurally similar to forest habitats (Ramírez-Marcial et al., 2017). Therefore, while many dung beetle species are restricted to forest patches, others may persist and use the second-growth forest matrix to move between forest patches (Díaz, Galante \& Favila, 2010). Second, fragmentation in variegated environments creates conditions that allow the coexistence of species from different habitat types (e.g., forest species, pasture species, edge specialist species), thereby increasing the diversity of dung beetles at the landscape scale (Villada-Bedoya et al., 2016; Fahrig, 2017).

Not all fragmentation effects are beneficial since a higher edge density can have adverse effects on the abundance, biomass, and even the physiological condition of tropical dung beetles (Portela Salomão et al., 2018). We found the lowest abundance of dung beetles in variegated windows, where the highest edge density occurs. A higher edge density is coupled with less habitat area, limiting the capacity of the landscape to support medium- and large-sized mammal species. Pozo-Montuy et al. (2019) observed that medium- and large-sized mammals are significantly less abundant and diverse in the REBISO buffer zone (i.e., where the variegated windows are located). Such reduction in mammal density can cause a marked decrease in dung quantity and availability, thus limiting the growth of dung beetle populations (Nichols et al., 2009). Also, microclimatic conditions such as temperature and relative humidity are more variable in forest edges, which might negatively affect the reproduction and survival of dung beetles (Klein, 1989; Feer, 2013). Our findings suggest that fragmentation processes in variegated windows foster a high dung beetle diversity, but might also limit their population growth due to insufficient resources, reduced habitat area, or sub-optimal microclimatic conditions. Future studies should assess the strength and extent of this trade-off between dung beetle diversity and abundance, and its functional consequences across the REBISO.

\section{Beta Diversity Patterns and Mechanisms of Diversity Maintenance}

Species turnover is the primary driver of the high diversity and complementarity of the dung beetle communities found in the REBISO. There were between 3 and 27 species not shared between windows, and from 4 to 35 species not shared between vegetation classes. Each window and vegetation class contributed two or three unique species to the overall diversity. The largest turnover values were found between the fragmented windows (W6, W7, and W8) vs. the variegated and intact windows (W1 to W5), and between the forested vegetation classes (tropical forest, second-growth forest) vs. the pasture sites. The anthropic disturbances and the heterogeneous landscape of REBISO favor this high beta diversity since dung beetles are especially susceptible to environmental variability (Arellano, Leon-Cortes \& Halffter, 2008; Costa et al., 2017).

The differences observed in the species assemblages of fragmented windows (W6, W7, and W8) and those in the other windows (W1 to W5) are not random. Likewise, the differences between tropical forest and pasture assemblages are not random. Significant deviations from random expectations of beta diversity indicate niche-structured assemblages in which

environmental filters determine species membership in a community (Chase et al., 2011; Püttker

Peer) reviewing PDF | (2020:03:46967:2:0:NEW 5 Aug 2020) 
426 et al., 2015). Intensive anthropic disturbances such as deforestation can act as an environmental 427 filter in fragmented windows and pastures, selecting stress-tolerant dung beetle species able to 428 survive in open habitats (Halffter, Favila \& Halffter, 1992; Spector \& Ayzama, 2003; Gardner et 429 al., 2008). Deltochilum mexicanum, C. vazquezae, S. chryseicollis, Canthon femoralis, and E. 430 maya probably are the species most sensitive to the environmental filters caused by anthropic 431 disturbance. Although these forest species are widely distributed in the biosphere reserve 432 (Sánchez-Hernández et al., 2018), their abundance was drastically reduced in fragmented 433 windows.

434 We found signs of biotic homogenization in the pasture sites. For instance, the lowest alfa 435 and beta diversity values were recorded in pastures, and their species assemblages were more 436 similar to each other than expected by chance, regardless of the windows where they were 437 located, indicating shared environmental filtering processes (Chase, 2010). Anthropogenic 438 environmental filters are one of the main drivers of biotic homogenization, eroding alfa and beta diversity and diminishing ecosystem resilience and viability (Gámez-Virués et al., 2015). Hence, the advance of the agricultural frontier in the REBISO landscape should be monitored closely to prevent further biotic homogenization processes among the dung beetle species assemblages.

In our study, ${ }^{1} \beta$ between the intact and variegated windows (W1 to W5), as well as between tropical forests and second-growth forests, was higher than ${ }^{0} \beta$. Thus, the true beta diversity is mainly due to differences in the abundance of shared species rather than to differences in richness (Jost, 2007). Besides, the overall beta diversity between these windows and vegetation classes was not different from that expected by chance. Most species in neutral communities are considered ecologically equivalent since, in the absence of any factor limiting their dispersal, they can appear at random in any of the null assemblages (Püttker et al., 2015; Ortega-Martínez et al., 2020). Both results suggest that the REBISO still holds sufficient vegetation cover to maintain a continuous flow of dung beetles between forested landscape sections (W1 to W5).

Given the significant stochasticity of beta diversity between intact and variegated windows, and between tropical forests and second-growth forests, we can conclude that the landscape variegation in the REBISO does not affect dung beetle diversity negatively. However, it is essential to conserve the forested patches to maintain a high dispersal between sites, thereby increasing the resilience of dung beetle populations to habitat loss and isolation (de Castro Solar et al., 2015; Socolar et al., 2016). Landscape variegation can be an effective strategy to buffer the impact of intense anthropic disturbances (Rös, Escobar \& Halffter, 2012; Costa et al., 2017). Variegation can be achieved by maintaining the forest cover and incorporating more biodiversity-friendly production systems, such as agroforestry practices, in the landscape matrix

461 (Perfecto \& Vandermeer, 2008).

462

463

\section{Conclusions}

464 
465 This research contributes to better understand how diversity is distributed in variegated

466 landscapes, and the role of heterogeneous landscapes in the conservation and management of

467 tropical biodiversity. Tropical forests and second-growth forests contributed significantly to

468 maintaining the diversity and biomass of dung beetle assemblages. The variegated structure of

469 the landscape fosters a high dung beetle diversity. The heterogeneity of the REBISO landscape

470 favors the formation of complementary dung beetle communities. Both deterministic and

471 stochastic processes drive the beta diversity patterns in the landscape. Intense anthropic

472 disturbances in fragmented windows and pastures act as non-stochastic filters upon dung beetle

473 species, eroding the alpha and beta diversity of these sites. By contrast, random processes govern

474 the less disturbed sites of the REBISO: fragmented tropical forests and second-growth forests.

475 Increasing habitat variegation in highly disturbed sites can be an effective strategy to buffer and

476 prevent further biotic homogenization processes.

477

478

479

\section{Acknowledgements}

480

481

482

We thank María Guadalupe Hernández López and Erick Hernández Baltazar for their assistance with data collection in the field. We thank Paula Enríquez, Alfonso González, Guillermo Ibarra,

483 and three anonymous reviewers for their valuable comments and suggestions. We thank the

484 communities of Emilio Rabasa, Nuevo San Juan Chamula, San Joaquin, and Tierra Nueva for

485 graciously granting access to their land to carry out our fieldwork. We also thank

486 REBISO/CONANP for providing logistic support. The postgraduate studies of José Daniel Rivera at Colegio de la Frontera Sur, San Cristóbal de las Casas, Chiapas, Mexico were supported by scholarships from CONACYT and the Heinrich Böll Stiftung Foundation. María Elena Sánchez-Salazar edited the English version of the manuscript.

490

\section{References}

492

Alvarado F, Dáttilo W, Escobar F. 2019. Linking dung beetle diversity and its ecological function in a gradient of livestock intensification management in the Neotropical region. Applied Soil Ecology 143:173-180. DOI: 10.1016/j.apsoil.2019.06.016.

Alvarado F, Escobar F, Williams DR, Arroyo-Rodríguez V, Escobar-Hernández F. 2018. The role of livestock intensification and landscape structure in maintaining tropical biodiversity. Journal of Applied Ecology 55:185-194. DOI: 10.1111/1365-2664.12957.

Alvarado F, Salomão RP, Hernandez-Rivera Á, de Araujo Lira AF. 2020. Different responses of dung beetle diversity and feeding guilds from natural and disturbed habitats across a subtropical elevational gradient. Acta Oecologica 104:103533. DOI: 10.1016/j.actao.2020.103533.

Arellano L, Leon-Cortes JL, Halffter G. 2008. Response of dung beetle assemblages to landscape structure in remnant natural and modified habitats in southern Mexico. Insect conservation and diversity 1:253-262. DOI: 10.1111/j.1752-4598.2008.00033.x. 
506

507

508

509

510

511

512

513

514

515

516

517

518

519

520

521

522

523

524

525

526

527

528

529

530

531

532

533

534

535

536

537

538

539

540

541

542

543

544

545

546

547

548

549

550

551

Arroyo-Rodríguez V, Melo FPL, Martínez-Ramos M, Bongers F, Chazdon RL, Meave JA, Norden N, Santos BA, Leal IR, Tabarelli M. 2017. Multiple successional pathways in human-modified tropical landscapes: new insights from forest succession, forest fragmentation and landscape ecology research. Biological Reviews 92:326-340. DOI: $10.1111 /$ brv. 12231.

Baselga A, Orme CDL. 2012. Betapart: An R package for the study of beta diversity. Methods in Ecology and Evolution 3:808-812. DOI: 10.1111/j.2041-210X.2012.00224.x.

Burnham KP, Anderson DR. 2002. Model Selection and Multimodel Inference: a practical information-theoretic approach. New York, USA: Springer.

Cajaiba R, Périco E, Schmidt Dalzochio M, Barreto da Silva W, Bastos R, Alexandre Cabral J, Santos M. 2017. Does the composition of Scarabaeidae ( Coleoptera ) communities reflect the extent of land use changes in the Brazilian Amazon? Ecological Indicators 74:285-294. DOI: 10.1016/j.ecolind.2016.11.018.

de Castro Solar RR, Barlow J, Ferreira J, Berenguer E, Lees AC, Thomson JR, Louzada J, Maués M, Moura NG, Oliveira VHF, Chaul JCM, Schoereder JH, Vieira ICG, Mac Nally R, Gardner TA. 2015. How pervasive is biotic homogenization in human-modified tropical forest landscapes? Ecology Letters 18:1108-1118. DOI: 10.1111/ele.12494.

Chao A, Gotelli NJ, Hsieh TC, Sander EL, Colwell RK. 2014. Rarefaction and Extrapolation with Hill Numbers: A Framework for Sampling and Estimation in Species Diversity Studies The Harvard community has made this article openly available. Please share how this access benefits you. Your story matters. Ecological Monographs 84:45-67. DOI: 10.1890/13-0133.1.

Chao A, Jost L. 2012. Coverage-based rarefaction and extrapolation: Standardizing samples by completeness rather than size. Ecology 93:2533-2547. DOI: 10.1890/11-1952.1.

Chase JM. 2010. Stochastic community assembly causes higher biodiversity in more productive environments. Science 328:1388-1391. DOI: 10.1126/science.1187820.

Chase JM, Kraft NJB, Smith KG, Vellend M, Inouye BD. 2011. Using null models to disentangle variation in community dissimilarity from variation in $\alpha$-diversity. Ecosphere 2:1-11. DOI: 10.1890/ES10-00117.1.

Chazdon RL, Harvey CA, Komar O, Griffith DM, Ferguson BG, Martínez-Ramos M, Morales H, Nigh R, Soto-Pinto L, Van Breugel M, Philpott SM. 2009. Beyond reserves: A research agenda for conserving biodiversity in human-modified tropical landscapes. Biotropica 41:142-153. DOI: 10.1111/j.1744-7429.2008.00471.x.

Costa C, Oliveira VHF, Maciel R, Beiroz W, Korasaki V, Louzada J. 2017. Variegated tropical landscapes conserve diverse dung beetle communities. PeerJ 5:e3125. DOI: 10.7717 peerj.3125.

Crawley M. 2013. The R Book. Chichester, UK.: John Wiley \& Sons. DOI: 10.1017/CBO9781107415324.004.

DeClerck FAJ, Chazdon R, Holl KD, Milder JC, Finegan B, Martinez-Salinas A, Imbach P, Canet L, Ramos Z. 2010. Biodiversity conservation in human-modified landscapes of Mesoamerica: Past, present and future. Biological Conservation 143:2301-2313. DOI: 10.1016/j.biocon.2010.03.026.

Díaz A, Galante E, Favila ME. 2010. The Effect of the Landscape Matrix on the Distribution of Dung and Carrion Beetles in a Fragmented Tropical Rain Forest. Journal of Insect Science 10:1-16. DOI: 10.1673/031.010.8101.

Domenici D. 2016. Arqueología de la selva El Ocote, Chiapas. In: Gorza P, Domenici D, 
552

553

554

555

556

557

558

559

560

561

562

563

564

565

566

567

568

569

570

571

572

573

574

575

576

577

578

579

580

581

582

583

584

585

586

587

588

589

590

591

592

593

594

595

596

597
Avitabile C eds. Mundos zoque y maya: miradas italianas. Mérida, México: Universidad Nacional Autónoma de México, 15-48.

Fahrig L. 2017. Ecological Responses to Habitat Fragmentation Per Se. Annual Review of Ecology, Evolution, and Systematics 48:annurev-ecolsys-110316-022612. DOI:

10.1146/annurev-ecolsys-110316-022612.

Favila ME. 2005. Diversidad alfa y beta de los escarabajos del estiércol (Scarabaeinae) en Los Tuxtlas México. In: Halffter G, Soberón J, Koleff P, Melic A eds. Sobre diversidad biológica: el significado de las diversidades alfa, beta y gamma. Zaragoza, España: Sociedad Entomológica Aragonesa, 209-219.

Favila ME, Halffter G. 1997. The use of indicator groups for measuring biodiversity as related to community structure and function. Acta Zoologica Mexicana Nueva Serie 0:1-25.

Feer F. 2013. Variations in dung beetles assemblages (Coleoptera: Scarabaeidae) within two rain forest habitats in French Guiana. Revista de Biologia Tropical 61:753-768.

Fischer J, Lindenmayer DB. 2007. Landscape modification and habitat fragmentation: a synthesis. Global Ecology and Biogeography 16:1-16. DOI: 10.1111/j.14668238.2006.00287.x.

Flamenco-Sandoval A, Martínez Ramos M, Masera OR. 2007. Assessing implications of landuse and land-cover change dynamics for conservation of a highly diverse tropical rain forest. Biological Conservation 138:131-145. DOI: 10.1016/j.biocon.2007.04.022.

Franklin JF, Lindenmayer DB. 2009. Importance of matrix habitats in maintaining biological diversity. Proceedings of the National Academy of Sciences 106:349-350. DOI: 10.1073/pnas.0812016105.

Gámez-Virués S, Perović DJ, Gossner MM, Börschig C, Blüthgen N, De Jong H, Simons NK, Klein AM, Krauss J, Maier G, Scherber C, Steckel J, Rothenwöhrer C, Steffan-Dewenter I, Weiner CN, Weisser W, Werner M, Tscharntke T, Westphal C. 2015. Landscape simplification filters species traits and drives biotic homogenization. Nature Communications 6. DOI: 10.1038/ncomms9568.

Gardner TA, Barlow J, Chazdon R, Ewers RM, Harvey CA, Peres CA, Sodhi NS. 2009. Prospects for tropical forest biodiversity in a human-modified world. Ecology Letters 12:561-582. DOI: 10.1111/j.1461-0248.2009.01294.x.

Gardner TA, Hernandez MIM, Barlow J, Peres CA. 2008. Understanding the biodiversity consequences of habitat change: the value of secondary and plantation forests for neotropical dung beetles. Journal of Applied Ecology 45:883-893. DOI: 10.1111/j.13652664.2008.01454.x.

Gotelli N, Colwell R. 2011. Estimating species richness. In: Biological Diversity. Frontiers in Measurement and Assessment. 39-54. DOI: 10.2307/3547060.

Grime JP. 1973. Competitive exclusion in herbaceous vegetation. Nature 242:344-346. DOI: $10.1038 / 246421 \mathrm{a} 0$.

Halffter G, Favila ME, Halffter V. 1992. A comparative study on the structure of the scarab guild in Mexican tropical rain forests and derived ecosystems. Folia Entomologica Mexicana 156:131-156.

Halffter G, Matthews E. 1966. The natural history of dung beetles of the subfamily Scarabaeinae (Coleoptera: Scarabaeidae). Folia Entomologica Mexicana 12:1-312.

Halffter G, Rös M. 2013. A Strategy for Measuring Biodiversity. Acta Zoológica Mexicana 29:400-411.

Hodder KH, Newton AC, Cantarello E, Perrella L. 2014. Does landscape-scale conservation 
598

599

600

601

602

603

604

605

606

607

608

609

610

611

612

613

614

615

616

617

618

619

620

621

622

623

624

625

626

627

628

629

630

631

632

633

634

635

636

637

638

639

640

641

642

643

management enhance the provision of ecosystem services? International Journal of Biodiversity Science, Ecosystem Services and Management 10:71-83. DOI: 10.1080/21513732.2014.883430.

Hothorn T, Bretz F, Westfall P, Heiberger R. M, Schuetzenmeister A, Scheibe S. 2016. multcomp: Simultaneous inference for general linear hypotheses. Cran:36.

Hsieh TC, Ma KH, Chao A. 2016. iNEXT: An R package for rarefaction and extrapolation of species diversity (Hill numbers). Methods in Ecology and Evolution 7:1451-1456. DOI: 10.1111/2041-210X.12613.

Jaeger J. 2000. Landscape division, splitting index, and effectivemesh size: new measures of landscape fragmentation. Landscape Ecology 15:115-130. DOI: 10.1023/A.

Jost L. 2006. Entropy and diversity. Oikos 113:363-375. DOI: 10.1111/j.2006.00301299.14714.x.

Jost L. 2007. Partitioning diversity into independent alpha and beta components. Ecology 88:2427-2439. DOI: 10.1890/06-1736.1.

Kelley K, Maxwell SE. 2003. Sample Size for Multiple Regression: Obtaining Regression Coefficients That Are Accurate, Not Simply Significant. Psychological Methods 8:305-321. DOI: $10.1037 / 1082-989 X .8 .3 .305$.

Klein B. 1989. Effects of Forest Fragmentation on Dung and Carrion Beetle Communities in Central Amazonia. Ecology 70:1715-1725.

Larsen TH, Forsyth A. 2005. Trap spacing and transect design for dung beetle biodiversity studies. Biotropica 37:322-325. DOI: 10.1111/j.1744-7429.2005.00042.x.

Legendre P. 2014. Interpreting the replacement and richness difference components of beta diversity. Global Ecology and Biogeography 23:1324-1334. DOI: 10.1111/geb.12207.

Legendre P, Legendre L. 2003. Numerical Ecology. Elsevier.

Lobo JM, Montes de Oca E. 1994. Distribución local y coexistencia de Digitonthophagus gazella (Fabricius, 1787) y Onthophagus batesi Howden \& Cartwright, 1963 (Coleoptera: Scarabaeidae). Elytron 8:117-127.

McGarigal K, Cushman S, Ene E. 2012. FRAGSTATS v4: Spatial Pattern Analysis Program for Categorical and Continuous Maps.

McIntyre S, Barret G. 1992. Habitat variegation, An alternative to fragmentation. Conservation Biology 6:146-147. DOI: 10.1046/j.1523-1739.1992.610146.x.

McIntyre S, Hobbs R. 1999. A framework for conceptualizing human effects on lanfscapes and its relevance fo management and research models. Conservation Biology 13:1282-1292. DOI: $10.1046 /$ j.1523-1739.1999.97509.x.

Melo FPL, Arroyo-Rodríguez V, Fahrig L, Martínez-Ramos M, Tabarelli M. 2013. On the hope for biodiversity-friendly tropical landscapes. Trends in Ecology and Evolution 28:462-468. DOI: $10.1016 /$ j.tree.2013.01.001.

Montes de Oca E, Halffter G. 1998. Invasion of Mexico By Two Dung Beetles Previously Introduced Into the United States. Studies on Neotropical Fauna and Environment 33:3745. DOI: 10.1076/snfe.33.1.37.2174.

Navarrete D, Halffter G. 2008. Dung beetle (Coleoptera: Scarabaeidae: Scarabaeinae) diversity in continuous forest, forest fragments and cattle pastures in a landscape of Chiapas, Mexico: The effects of anthropogenic changes. Biodiversity and Conservation 17:2869-2898. DOI: 10.1007/s10531-008-9402-8.

Nichols E, Gardner TA, Peres CA, Spector S, Network SR. 2009. Co-declining mammals and dung beetles: an impending ecological cascade. Oikos 118:481-487. DOI: 10.1111/j.1600- 
644

645

646

647

648

649

650

651

652

653

654

655

656

657

658

659

660

661

662

663

664

665

666

667

668

669

670

671

672

673

674

675

676

677

678

679

680

681

682

683

684

685

686

687

688

689

0706.2009.17268.x.

Nichols E, Larsen T, Spector S, Davis a. L, Escobar F, Favila M, Vulinec K. 2007. Global dung beetle response to tropical forest modification and fragmentation: A quantitative literature review and meta-analysis. Biological Conservation 137:1-19. DOI: 10.1016/j.biocon.2007.01.023.

Nichols E, Spector S, Louzada J, Larsen T, Amezquita S, Favila ME, The Scarabaeinae Research Network. 2008. Ecological functions and ecosystem services provided by Scarabaeinae dung beetles. Biological Conservation 141:1461-1474. DOI: 10.1016/j.biocon.2008.04.011.

Numa C, Verdú JR, Sánchez a., Galante E. 2009. Effect of landscape structure on the spatial distribution of Mediterranean dung beetle diversity. Diversity and Distributions 15:489501. DOI: 10.1111/j.1472-4642.2009.00559.x.

Nunes CA, Braga RF, de Moura Resende F, de Siqueira Neves F, Figueira JEC, Fernandes GW. 2018. Linking Biodiversity, the Environment and Ecosystem Functioning: Ecological Functions of Dung Beetles Along a Tropical Elevational Gradient. Ecosystems 21:12441254. DOI: 10.1007/s10021-017-0216-y.

Ochoa S. 1996. La vegetación de la Reserva El Ocote a lo largo del cañon del rio La Venta. In: Vasquez Sánches MA, March Mifsut I eds. Conservación y desarrollo sustentable en la Selva El Ocote, Chiapas. 45-86.

Ortega-Martínez IJ, Moreno CE, Rios-Díaz CL, Arellano L, Rosas F, Castellanos I. 2020. Assembly mechanisms of dung beetles in temperate forests and grazing pastures. Scientific Reports 10:1-10. DOI: 10.1038/s41598-019-57278-x.

Peralta Moctezuma JV. 2019. Escarabajos del estiércol (scarabaeinae) de los chimalapas, méxico: análisis taxonómico, ecológico y evolutivo. Instituto de Ecología, A.C.

Perfecto I, Vandermeer J. 2008. Biodiversity conservation in tropical agroecosystems: A new conservation paradigm. Annals of the New York Academy of Sciences 1134:173-200. DOI: 10.1196/annals. 1439.011.

Portela Salomão R, González-Tokman D, Dáttilo W, López-Acosta JC, Favila ME. 2018. Landscape structure and composition define the body condition of dung beetles (Coleoptera: Scarabaeinae) in a fragmented tropical rainforest. Ecological Indicators 88:144-151. DOI: 10.1016/j.ecolind.2018.01.033.

Pozo-Montuy G, Camargo-Sanabria AA, Cruz-Canuto I, Leal-aguilar K, Mendoza E. 2019. Análisis espacial y temporal de la estructura de la comunidad de mamíferos medianos y grandes de la Reserva de la Biosfera Selva El Ocote, en el sureste mexicano. Revista mexicana de biodiversidad 90:e902731.

Püttker T, de Arruda Bueno A, Prado PI, Pardini R. 2015. Ecological filtering or random extinction? Beta-diversity patterns and the importance of niche-based and neutral processes following habitat loss. Oikos 124:206-215. DOI: 10.1111/oik.01018.

QGIS Development Team. 2016. QGIS Geographic Information System.

Quintero I, Roslin T. 2005. Rapid Recovery of Dung Beetle Communities Following Habitat Fragmentation in Central Amazonia. Ecology 86:3303-3311.

R Development Core Team. 2015. R: A Language and Environment for Statistical Computing. Ramírez-Marcial NM, Martínez-Icó M, Luna Gómez A, Buet C, Taylor Aquino NE. 2017. Diversidad local y regional de árboles en la Reserva de la Biósfera Selva El Ocote, Chiapas. In: Álvarez-Gordillo G, Ramírez-Marical N, Ruiz-Montoya L eds. Vulnerabilidad social y biológica en la Reserva de la Biosfera Selva El Ocote. Chiapas, México: El Colegio de la Frontera Sur, En Prensa. 
690

691

692

693

694

695

696

697

698

699

700

701

702

703

704

705

706

707

708

709

710

711

712

713

714

715

716

717

718

719

720

721

722

723

724

725

726

727

728

729

730
Ramírez-Ponce A, Calderón-Patrón JM, Vásquez HMG, Moreno CE. 2019. Biotic heterogeneity among scarab beetle communities in an anthropized landscape in the Central Valleys of Oaxaca, Mexico. Journal of Insect Conservation 23:765-776. DOI: 10.1007/s10841-01900169-3.

Rös M, Escobar F, Halffter G. 2012. How dung beetles respond to a human-modified variegated landscape in Mexican cloud forest: A study of biodiversity integrating ecological and biogeographical perspectives. Diversity and Distributions 18:377-389. DOI: 10.1111/j.1472-4642.2011.00834.x.

Sánchez-de-Jesús HA, Arroyo-Rodríguez V, Andresen E, Escobar F. 2016. Forest loss and matrix composition are the major drivers shaping dung beetle assemblages in a fragmented rainforest. Landscape Ecology 31:843-854. DOI: 10.1007/s10980-015-0293-2.

Sánchez-Hernández G, Gómez B, Delgado L, Rodríguez-López ME, Chamé-Vázquez ER. 2018. Diversidad de escarabajos copronecrófagos (Coleoptera: Scarabaeidae: Scarabaeinae) en la Reserva de la Biosfera Selva El Ocote, Chiapas, México. Caldasia 40:144-160.

Schoereder JH, Galbiati C, Ribas CR, Sobrinho TG, Sperber CF, DeSouza O, Lopes-Andrade C. 2004. Should we use proportional sampling for species - area studies ? Journal of Biogeography 31:1219-1226. DOI: 10.1111/j.1365-2699.2004.01113.x.

SEMARNAT/CONANP. 2001. Programa de Manejo Reserva de la Biosfera Selva El Ocote. Chiapas, México: Secretaria de Medio Ambiente y Recursos Naturales.

Silva RJ, Storck-Tonon D, Vaz-de-Mello FZ. 2016. Dung beetle (Coleoptera: Scarabaeinae) persistence in Amazonian forest fragments and adjacent pastures: biogeographic implications for alpha and beta diversity. Journal of insect conservation 20:549-564. DOI: 10.1007/s10841-016-9885-7.

Socolar JB, Gilroy JJ, Kunin WE, Edwards DP. 2016. How Should Beta-Diversity Inform Biodiversity Conservation? Trends in Ecology and Evolution 31:67-80. DOI: 10.1016/j.tree.2015.11.005.

Spector S, Ayzama S. 2003. Rapid turnover and edge effects in dung beetle assemblages (Scarabaeidae) at a Bolivian Neotropical forest-savanna ecotone. Biotropica 35:394-404.

Tscharntke T, Tylianakis JM, Rand TA, Didham RK, Fahrig L, Batáry P, Bengtsson J, Clough Y, Crist TO, Dormann CF, Ewers RM, Fründ J, Holt RD, Holzschuh A, Klein AM, Kleijn D, Kremen C, Landis DA, Laurance W, Lindenmayer D, Scherber C, Sodhi N, SteffanDewenter I, Thies C, van der Putten WH, Westphal C. 2012. Landscape moderation of biodiversity patterns and processes - eight hypotheses. Biological Reviews 87:661-685. DOI: $10.1111 /$ j.1469-185X.2011.00216.x.

Vilela B, Villalobos F. 2015. LetsR: A new R package for data handling and analysis in macroecology. Methods in Ecology and Evolution 6:1229-1234. DOI: 10.1111/2041210X.12401.

Villada-Bedoya S, Cultid-Medina CA, Escobar F, Guevara R, Zurita G. 2016. Edge effects on dung beetle assemblages in an Andean mosaic of forest and coffee plantations. Biotropica 0:1-11. DOI: 10.1111/btp.12373. 
Figure 1

Study area showing the location of the sampling windows at the Biosphere Reserve Selva El Ocote, Chiapas.
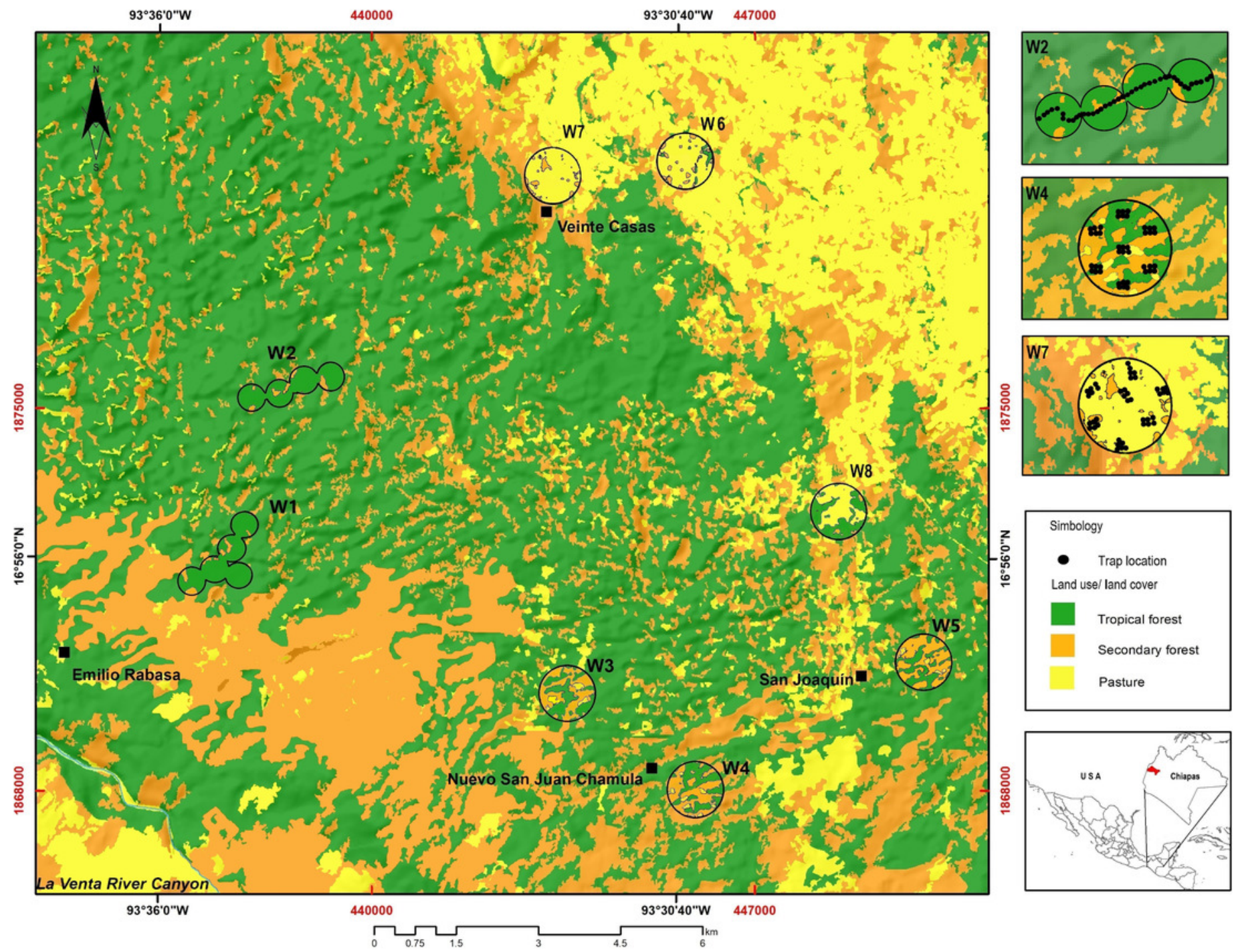
Figure 2

(A) Observed species richness of dung beetles per window (W); (B) Interpolationextrapolation species accumulation curve per vegetation class.

95\% bootstrap confidence intervals are shown for observed richness per window and the species accumulation curves per vegetation class; (A) Intact Landscapes: W1, W2; Variegated Landscapes: W3, W4, W5; Fragmented Landscapes: W6, W7, W8; (B) Circle: Forest; Triangle: Second-growth forest, Square: Pasture. The red vertical line at the end of the species extrapolation curve of the second-growth forest represents the base sample size for comparison of species richness between vegetation classes.
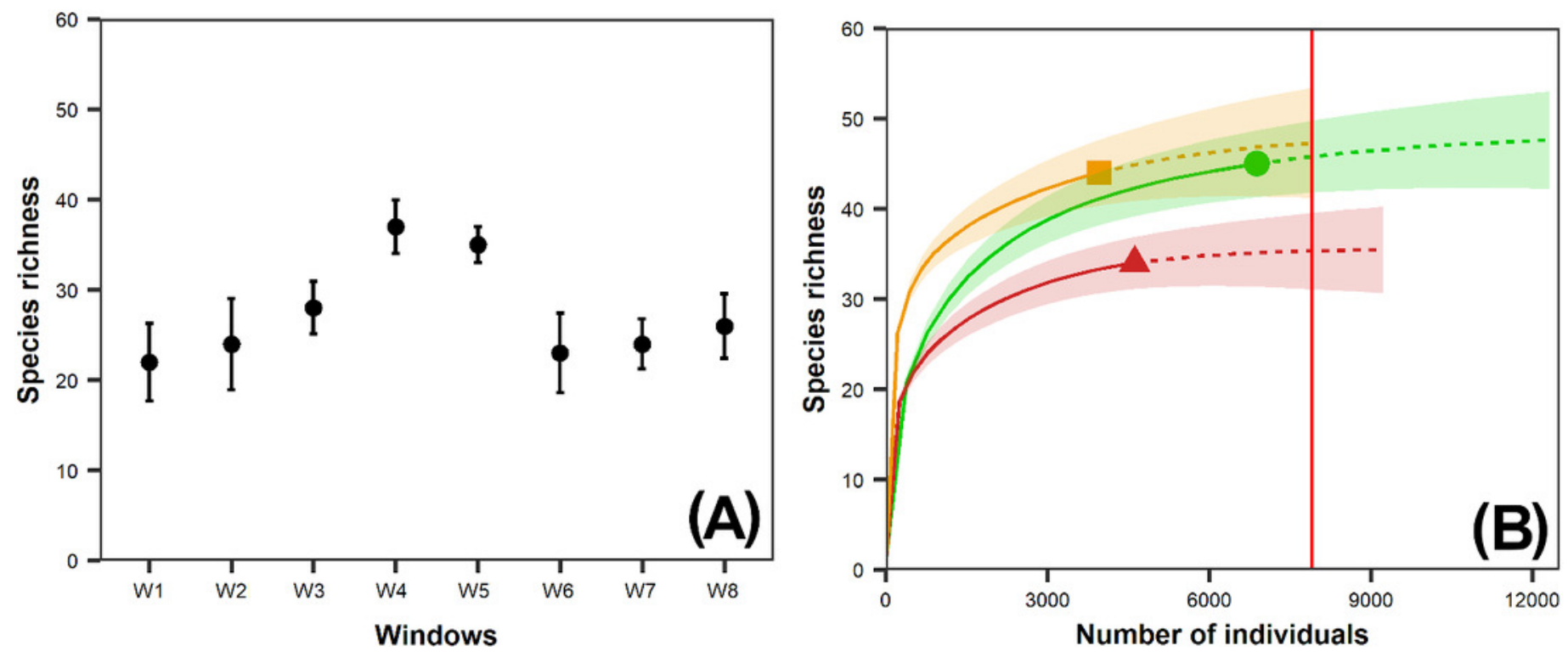
Figure 3

(A) Beta diversity within windows; Dendrogram based on (B) Sørensen dissimilarity between windows \& (C) $\beta R-C$ dissimilarity between windows .

(A) Black dots: Sørensen beta diversity ( $\beta$ Sor) between windows. White bars: Percentage contribution of species turnover ( $\beta$ Sim) to beta diversity ( $\beta$ Sim/ $\beta$ Sor); Black bars: Percentage contribution of species-nestedness ( $\beta$ Sne) to beta diversity ( $\beta$ Sne/ $\beta$ Sor). 

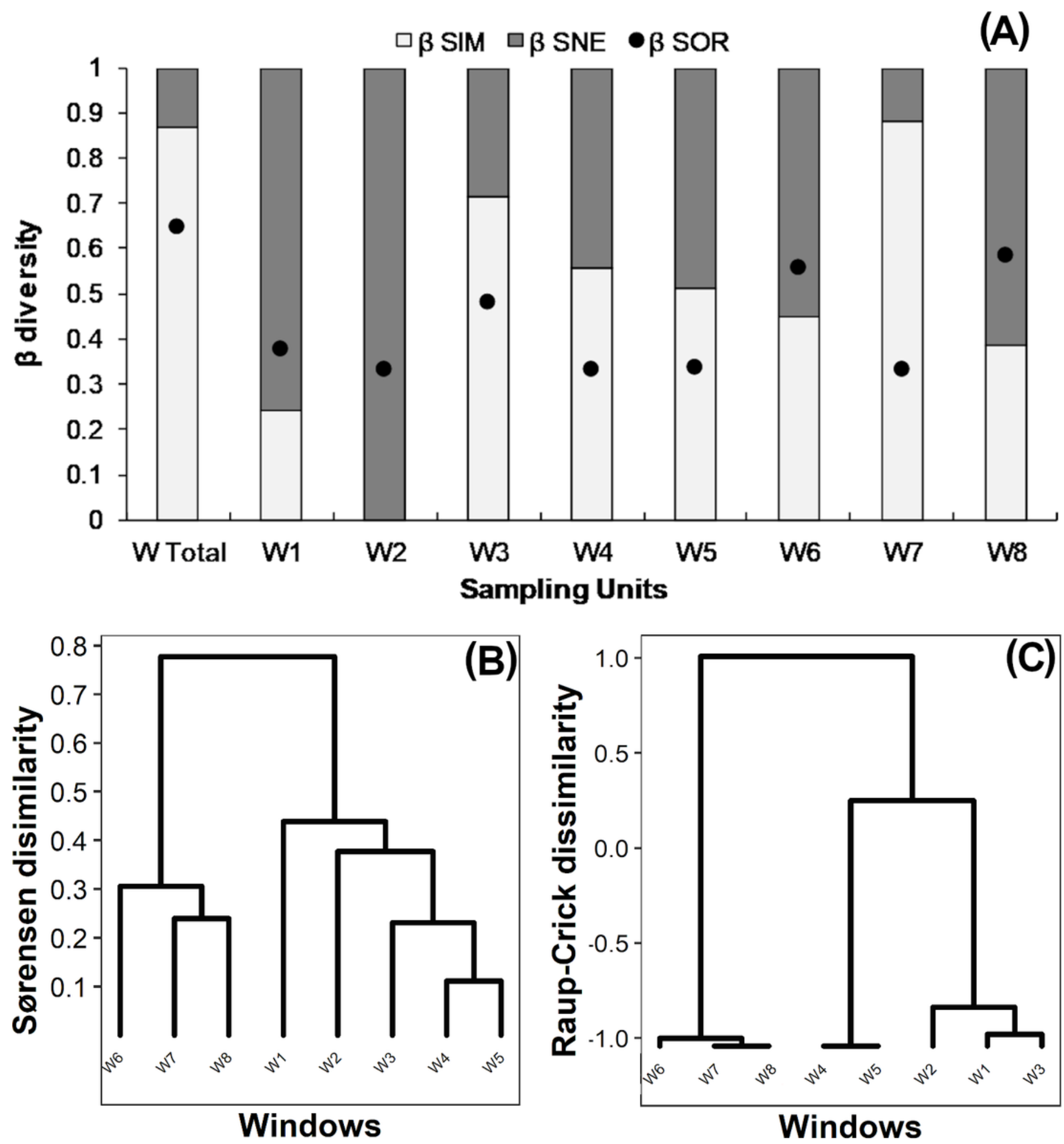


\section{Figure 4}

(A) Beta diversity within vegetation classes; Non-metric Multidimensional scaling ordination for vegetation classes based on (B) Sørensen dissimilarity \& (C) BR-C dissimilarity.

(A) Black dots: Sørensen beta diversity ( $\beta$ Sor) between vegetation classes. White bars:

Percentage contribution of species turnover ( $\beta$ Sim) to beta diversity ( $\beta$ Sim/ $\beta$ Sor), black bars:

Percentage contribution of species-nestedness ( $\beta$ Sne) to beta diversity ( $\beta$ Sne/ $\beta$ Sor); (B \& C)

F: Forest, SF: Second-growth forest, P: Pasture. 

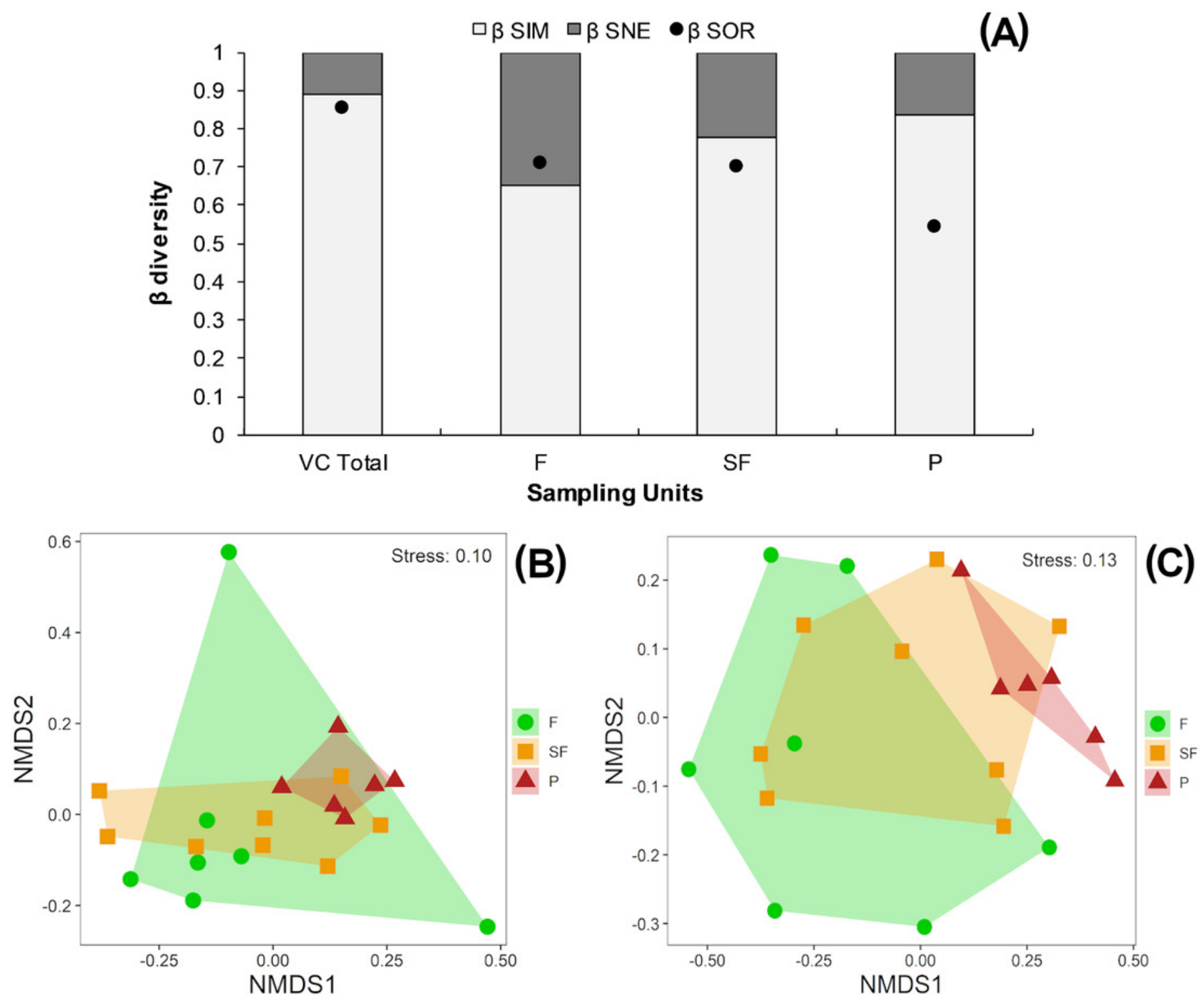


\section{Table 1 (on next page)}

Vegetation classes found at Reserva de la Biosfera Selva El Ocote, Mexico. 


\begin{tabular}{|c|c|}
\hline Vegetation class & Description \\
\hline $\begin{array}{l}\text { Tropical forest } \\
\text { (n=7): }{ }^{338 \%} \\
\text { W1, W2, W3, W4, } \\
\text { W5, W6, W8. }\end{array}$ & $\begin{array}{l}\text { Forest in a mature successional stage with a dense canopy cover. The } \\
\text { most common tree species are Pseudolmedia spuria, Louteridium } \\
\text { donnell-smithii, Manilkara sapota, Swietenia macrophylla and } \\
\text { Quararibea funebris (SEMARNAT/CONANP 2001; Ramírez- } \\
\text { Marcial et al. } 2017) \text {. Mean canopy cover, } 82.32 \% \text { ( } \pm 1.35 \text { s.e. }) \text {; mean } \\
\text { basal area, } 912.24 \mathrm{~cm}^{2}( \pm 163.88 \text { s.e. }) \text {. }\end{array}$ \\
\hline $\begin{array}{l}\text { Second-growth forest } \\
(\mathrm{n}=8):{ }^{\mathrm{a} 30 \%} \\
\mathrm{~W} 1, \mathrm{~W} 2, \mathrm{~W} 3, \mathrm{~W} 4 \\
\text { W5, W6, W7, W8 }\end{array}$ & $\begin{array}{l}\text { Forest in intermediate successional stage, recovering after } 1998 \text { fire; } \\
\text { the canopy is less dense than in the tropical forest. Dominated by } \\
\text { Heliocarpus appendiculatus and Eugenia acapulcensis } \\
\text { (SEMARNAT/CONANP, } 2001 \text {; Ramírez-Marcial et al. } 2017) \text {. Mean } \\
\text { canopy cover, } 56.76 \%\left( \pm 3.22 \text { s.e.); mean basal area, } 577.65 \mathrm{~cm}^{2}( \pm\right. \\
105.14 \text { s.e.). }\end{array}$ \\
\hline $\begin{array}{l}\text { Pasture }(n=5):{ }^{\text {a32\% }} \\
\text { W3, W4, W5, W6, } \\
\text { W7, W8 }\end{array}$ & $\begin{array}{l}\text { Pastures are at least ten years old (SEMARNAT/CONANP, } 2001) \text {. } \\
\text { The few trees present are used mainly as shade for cattle. Mean basal } \\
\text { area, } 874.29 \mathrm{~cm}^{2}( \pm \text { s.e. } 94.60) \text {; canopy cover ranges from } 2 \% \text { to } \\
53 \%(\bar{x} 22.11 \%, \pm \text { s.e } 3.03) \text {. }\end{array}$ \\
\hline
\end{tabular}

a Mean coverage over the eight windows. 


\section{Table 2 (on next page)}

${ }^{0} D$ and ${ }^{1} D$ values in each window and vegetation class at Reserva de la Biosfera Selva El Ocote, Mexico.

F: Forest; SF: Second-growth forest; P: Pasture 


\begin{tabular}{|c|c|c|c|c|c|c|c|c|}
\hline \multicolumn{5}{|c|}{${ }^{0} \mathbf{D}$} & \multicolumn{4}{|c|}{${ }^{1} \mathbf{D}$} \\
\hline & $\mathbf{F}$ & SF & $\mathbf{P}$ & $\begin{array}{l}\text { Species } \\
\text { richness }\end{array}$ & $\mathbf{F}$ & SF & $\mathbf{P}$ & $\begin{array}{c}\text { Exp (Shannon } \\
\text { diversity) }\end{array}$ \\
\hline W1 & 22 & 11 & - & 22 & 5.23 & 4.8 & - & 5.36 \\
\hline W2 & 24 & 12 & - & 24 & 5.05 & 4.27 & - & 4.97 \\
\hline W3 & 21 & 21 & 11 & 28 & 7.71 & 7.22 & 5.38 & 8.69 \\
\hline W4 & 31 & 29 & 20 & 37 & 12.39 & 13.51 & 13.91 & 16.49 \\
\hline W5 & 27 & 32 & 19 & 35 & 9.88 & 16.37 & 9.55 & 17.59 \\
\hline W6 & 5 & 14 & 19 & 23 & 3.50 & 5.51 & 6.40 & 6.57 \\
\hline W7 & - & 17 & 19 & 24 & - & 8.08 & 7.38 & 7.61 \\
\hline W8 & 2 & 20 & 21 & 26 & 1.50 & 3.46 & 9.51 & 5.49 \\
\hline$\gamma$ & 45 & 44 & 34 & $55^{a} / 55^{b}$ & 7.75 & 15.54 & 8.93 & $15.84^{a} / 15.84^{b}$ \\
\hline$\alpha$ & 18.85 & 19.5 & 18.66 & $27.37^{a} / 18.9^{b}$ & 2.93 & 6.57 & 7.34 & $7.09^{a} / 6.15^{b}$ \\
\hline$\beta$ & 2.38 & 2.25 & 1.87 & $2.01^{\mathrm{a} / 2.9^{\mathrm{b}}}$ & 2.64 & 2.36 & 1.21 & $2.23^{\mathrm{a} / 2.57^{\mathrm{b}}}$ \\
\hline
\end{tabular}

1 a Overall window diversity, ${ }^{\mathbf{b}}$ Overall vegetation class diversity. 


\section{Table 3 (on next page)}

Mean abundance and biomass $(\mathrm{g})$ per trap $( \pm \mathrm{sd})$ in each window and vegetation class.

F: Forest; SF: Second-growth forest; P: Pasture. Pairwise comparison results are shown in Table S5. Different letters indicate statistically significant differences between windows and between vegetation classes $(P<0.05)$. 


\begin{tabular}{lcc|cc}
\hline & Mean abundance/trap $( \pm \mathbf{s d})$ & $\mathbf{P}<\mathbf{0 . 0 5}$ & Mean biomass/trap $( \pm \mathbf{s d})$ & $\mathbf{P}<\mathbf{0 . 0 5}$ \\
\hline W1 & $52.94(11.13)$ & $\mathrm{a}$ & $9.07(1.01)$ & $\mathrm{a}$ \\
W2 & $44.95(0.11)$ & $\mathrm{a}$ & $8.20(0.93)$ & $\mathrm{a}, \mathrm{b}$ \\
W3 & $20.83(13.94)$ & $\mathrm{a}$ & $2.37(0.97)$ & $\mathrm{c}$ \\
W4 & $15.72(7.88)$ & $\mathrm{a}$ & $2.53(0.72)$ & $\mathrm{c}$ \\
W5 & $29.55(10.88)$ & $\mathrm{a}$ & $3.89(1.70)$ & $\mathrm{b}, \mathrm{c}$ \\
W6 & $15.82(5.12)$ & $\mathrm{a}$ & $2.20(0.49)$ & $\mathrm{c}$ \\
W7 & $35.26(18.29)$ & $\mathrm{a}$ & $2.75(0.05)$ & $\mathrm{c}$ \\
W8 & $36.51(46.98)$ & $\mathrm{a}$ & $3.71(1.22)$ & $\mathrm{b}, \mathrm{c}$ \\
\hline F & $30.28(13.91)$ & $\mathrm{a}$ & $5.05(2.21)$ & $\mathrm{a}$ \\
SF & $37.89(26.86)$ & $\mathrm{a}$ & $4.53(3.04)$ & $\mathrm{a}$ \\
P & $17.74(15.56)$ & $\mathrm{a}$ & $2.09(0.62)$ & $\mathrm{b}$ \\
\hline
\end{tabular}

1

2 


\section{Table 4 (on next page)}

Estimated parameters of the best-fit General Linear Models (GLMs) for the effect of landscape composition and configuration on species richness, diversity, abundance, and biomass of dung beetles.

The best-fit GLMs for each response variable are shown, ordered from the best to the worst.

Species richness $\left({ }^{0} D\right)$, exponential Shannon Diversity $\left({ }^{1} D\right)$, abundance $(A b)$, biomass $(B m)$.

FC: \% forest cover; SHDI: landscape diversity; PLAND: percentage of each vegetation class in a window; SPLIT: splitting index; ED: edge density; $D^{2}$ : explained deviance. 


\begin{tabular}{|c|c|c|c|c|c|c|c|}
\hline GLMs & Parameters & Estimate & S.E. & t value & $P$-value & AICc & $\overline{\mathbf{D}^{2}}$ \\
\hline \multirow[t]{2}{*}{${ }^{0} \mathrm{D} \sim \mathrm{SPLIT}$} & Intercept & 18.991 & 0.787 & 24.110 & $<0.001$ & 34.955 & 0.95 \\
\hline & SPLIT & 2.696 & 0.215 & 12.520 & $<0.001$ & & \\
\hline \multirow[t]{2}{*}{${ }^{0} \mathrm{D} \sim \mathrm{SHDI}$} & Intercept & 10.693 & 5.44 & 1.965 & 0.097 & 53.513 & 0.47 \\
\hline & SHDI & 8.640 & 2.73 & 3.161 & 0.019 & & \\
\hline \multirow[t]{2}{*}{${ }^{0} \mathrm{D} \sim \mathrm{ED}$} & Intercept & 18.415 & 3.292 & 5.593 & 0.001 & 54.052 & 0.43 \\
\hline & ED & 0.0761 & 0.025 & 2.99 & 0.024 & & \\
\hline \multirow[t]{2}{*}{${ }^{0} \mathrm{D} \sim \mathrm{FC}$} & Intercept & 27.842 & 3.221 & 8.643 & $<0.001$ & 61.306 & 0.00 \\
\hline & $\mathrm{FC}$ & -0.012 & 0.063 & -0.195 & 0.851 & & \\
\hline \multirow{2}{*}{${ }^{1} \mathrm{D} \sim$ SPLIT } & Intercept & 2.026 & 1.405 & 1.443 & 0.199 & 44.206 & 0.79 \\
\hline & SPLIT & 2 & 0.384 & 5.921 & 0.001 & & \\
\hline \multirow[t]{2}{*}{${ }^{1} \mathrm{D} \sim \mathrm{ED}$} & Intercept & 1.570 & 3.202 & 0.490 & 0.641 & 53.606 & 0.34 \\
\hline & ED & 0. & 0.025 & 2.584 & 0.041 & & \\
\hline \multirow[t]{2}{*}{${ }^{1} \mathrm{D} \sim \mathrm{SHDI}$} & Intercept & -3.447 & 5.951 & -0.579 & 0.583 & 54.947 & 0.22 \\
\hline & SHDI & 6.4 & 2.989 & 2.173 & 0.073 & & \\
\hline \multirow[t]{2}{*}{${ }^{1} \mathrm{D} \sim \mathrm{FC}$} & Intercept & 9.628 & 2.879 & 3.344 & 0.015 & 59.510 & 0.00 \\
\hline & $\mathrm{FC}$ & -0.014 & 0.056 & -0.248 & 0.812 & & \\
\hline \multirow[t]{2}{*}{$\overline{\mathrm{Ab} \sim \mathrm{ED}}$} & Intercept & 4.047 & 0.308 & 13.146 & $<0.001$ & 16.136 & 0.28 \\
\hline & EI & & 0.002 & -2.387 & & & \\
\hline \multirow{2}{*}{$\mathrm{Ab} \sim \mathrm{SHDI}$} & Intercept & 4.524 & 0.554 & 8.164 & $<0.001$ & 16.968 & 0.20 \\
\hline & SHDI & -0.593 & 0.278 & -2.131 & 0.072 & & \\
\hline \multirow[t]{2}{*}{$\mathrm{Ab} \sim \mathrm{FC}$} & Intercept & 3.176 & 0.243 & 13.070 & $<0.001$ & 19.952 & 0.00 \\
\hline & $\mathrm{FC}$ & & 0.005 & 1.123 & 0.305 & & \\
\hline \multirow[t]{2}{*}{$\mathrm{Ab} \sim \mathrm{SPLIT}$} & Intercept & 3.648 & 0.314 & 11.629 & $<0.001$ & 20.222 & 0.00 \\
\hline & SPLIT & -0.086 & 0.086 & -1.009 & 0.32 & & \\
\hline \multirow[t]{2}{*}{$\mathrm{Bm} \sim \mathrm{FC}$} & Intercept & 1.752 & 0.696 & 2.517 & 0.045 & 36.795 & 0.70 \\
\hline & $\mathrm{FC}$ & & 0.014 & 4.678 & & & \\
\hline \multirow[t]{2}{*}{$\mathrm{Bm} \sim \mathrm{ED}$} & Intercept & 8.037 & 1.6780 & 4.785 & 0.003 & 43.284 & 0.32 \\
\hline & & & 0.013 & & & & \\
\hline \multirow[t]{2}{*}{ Bm SHDI } & Intercept & 9.910 & 3.346 & 2.962 & 0.025 & 45.773 & 0.08 \\
\hline & & & 1.681 & -1.767 & 0.127 & & \\
\hline \multirow[t]{2}{*}{$\mathrm{Bm} \sim \mathrm{SPLIT}$} & Intercept & 5.114 & 1.851 & 2.763 & 0.032 & 48.624 & 0.00 \\
\hline & SPLIT & -0.302 & 0.506 & -0.597 & 0.572 & & \\
\hline
\end{tabular}

